\title{
Barriers of Public Sector Innovation: A Case Study in The Alley Garden Program in Makassar City
}

\author{
Gita Susanti ${ }^{1}$, Andi Ahmad Yani², Muhammad Irvan Nur Iva ${ }^{3}$, Siti Halwatiah ${ }^{4}$, \\ Andi Rahmat Hidayat ${ }^{5}$, Alfiana ${ }^{6}$ \\ \{gitasusanti65@gmail.com¹, aayani@unhas.ac.id²,m.irvan.nuriva@gmail.com³, \\ sitihalwatiah@gmail.com ${ }^{4}$, andirahmatfisipuh@gmail.com ${ }^{5}$, alfianahafid@yahoo.com $\left.{ }^{6}\right\}$
}

Department of Administrative Science, Faculty of Social and Political Science, Hasanuddin University, Jl. Perintis Kemerdekaan KM. 10, Makassar, Indonesia ${ }^{1,2,3,4,5,6}$

\begin{abstract}
This study aims to identify barriers experienced in public sector innovation with a case study of the Alley Garden (LONGGAR) program innovation in Makassar. The measurement indicators used include several inhibiting factors according to Mulgan and Albury. The data collection method uses a qualitative description method through observation, interviews and documentation studies. The technique of determining the informant is done by purposive sampling. Data analysis was obtained through the stages of data reduction, data presentation and drawing conclusions. The results illustrate that the government must make budget transparency, LONGGAR Standard Operating Procedures (SOP), and optimization of the involvement of youth and community leaders. Through identifying these obstacles, the government can use this information and minimize the failure to apply Lorong Garden innovations in Makassar City and other regional contexts.
\end{abstract}

Keywords: Barriers to Public Sector Innovation, public Sector Innovation, innovation program

\section{Introduction}

The public sector is reaping demands for change to be more flexible and able to answer the challenges of community dynamics. Innovation is an obligation and a need for governments at all levels because innovation is the answer to problems faced by the public sector[1]. Innovation can be something tangible or intangible. In this context, the dimensions of innovation are very broad. Understanding innovation as appropriate that is only identical with technology alone will narrow the actual context of innovation [2]. Mulgan and Albury stated several reasons why the public sector must innovate: (1) innovation is carried out to respond more effectively to changes in the needs and expectations of the public that continue to increase; (2) to include cost elements and to improve efficiency; (3) to improve the delivery of public services, including those in the past which have made little progress; (4) to capitalize on the full use of ICT, as this has been proven to increase efficiency and effectiveness in service delivery[3].

The Makassar City Government is responsible for the development of its territory in accordance with the socio-cultural context and Law No. 9 of 2015 concerning Regional Government. The city of Makassar has a sizeable population density in Indonesia of 1,671,001 People in 2018 with a growth rate of 0.09 [4]. Uncontrolled growth in urban population has led 
to the emergence of land clearing activities for settlements. Space needs are increasing to accommodate the needs of urban dwellers. The increasing amount of demand for urban space results in deterioration in environmental quality[5].

The increasing population density of Makassar City has caused problems with land conversion and changes in land use intensity. This causes a reduction in green open space, both private and public proportions. Access roads that are increasingly narrow are the effects of shifting use of space. This affects the condition of the aisle that is not maintained and affects the visual quality of the environment and socio-cultural degradation[5]. Therefore, Lorong Garden (LONGGAR) is a manifestation of the Makassar City Government's innovation in resolving these problems, in accordance with its vision of "Mewujudkan Kota Dunia yang Nyaman untuk Semua, Tata Lorong Bangun Kota Dunia" or in English "Creating a Comfortable World City for All, Manage the Alleys to Develop World City".

The LONGGAR program was developed into a productive program like urban farming with an agricultural concept in the massive urban sphere developed into infill Agriculture. The LONGGAR program changes the face of the hallway to be attractive and changes the community's perception of the hallway to be more positive and productive. The city allies are filled with vertical gardens planted with productive plants which can be consumed and sold at harvest time. Therefore, it can be said that the program is a driving force for the community's economy.

Local government innovation must be in line with the expected achievements of the innovation targets[3]. Innovation does not happen smoothly or without resistance. Many innovations of which are precisely constrained by various factors. In the context of the LONGGAR program innovation, there are obstacles that affect the performance of the innovation.

The inhibiting factors for innovation proposed by Mulgan and Albury[3] are: (1) Reluctance to closed own filing program or organization, (2) Over-reliance on high performers as source of innovation, (3) Technologies available but constraining cultural or organizational arrangement, (4) No rewards or incentives to innovate or adopt innovations, (5) Poor skills in active risk or change management, (6) Short-term budget and planning horizons, (7) Delivery pressures and administrative burdens, (8) Culture of risk aversion.

Synchronization between LONGGAR and indication of inhibiting factors in its application is the focus of this study. The aim is to identify obstacles to public sector innovation through case studies of Lorong Garden program innovation in Makassar.

\section{Research Method}

The study uses a qualitative approach that is to find out or describe the reality and events the under study to facilitate the determination of objective data[6]. The focus of the research is public sector innovation barriers in the implementation of LONGGAR program in Makassar. The type of data processed consists of primary data that is the main data obtained from in-depth observations, in-depth interviews with the community and local government. Then secondary data is supporting data obtained through literature review and document studies. The technique of determining informants is by purposive sampling, where the determination of the sample in research is not done in the entire population, but focus on the target by considering certain criteria according to the research objectives. Qualitative data analysis techniques by carefully 
abstracting every information obtained through three stages namely data reduction, data presentation and conclusion drawing[7].

\section{Result and Discussion}

The Lorong Garden (LONGGAR) program was implemented in 2015. As a manifestation of the achievement of "Clean Makassar" and the main program of each district and sub-district in Makassar City, the Chairperson of RW, RT and community leaders worked together to create the LONGGAR program in their community. The objectives of this program are: increasing the quality of the aisles, raising public awareness, strengthening community friendship, minimizing criminal acts and contributing to the community's economy. This encouraged the emergence of the flagship program "1000 LONGGAR Movement", by arranging 7,520 aisles in Makassar City.

The 1000 LONGGAR program certainly not only changed the face of the dirty and arid alleyways in Makassar to be clean and green, but also can make contribution to community's economy. Through urban farming, the city halls are filled with vertical gardens planted with productive plants such as vegetables and fruit and ornamental plants. At harvest time, it can be consumed by residents and can also be sold. Green and Productive are the colours of allies[5].

LONGGAR includes an innovation system with fundamental changes from existing systems by establishing new interactions[5]. As a public sector innovation, LONGGAR is not an attempt to fill in and interpret rules following local conditions[8]. Therefore, it is important to identify barriers to the application of LONGGAR and the following eight indicators for measuring the inhibiting factors of public sector innovation[3] as follows:

\subsection{Reluctance to close down filing program or organization,}

A program or even organizational unit that has clearly demonstrated failure will be better closed and replaced with a more promising new program or unit. Every innovation must be open to failure and improvement. LONGGAR program is the first innovation in Indonesia, specifically the acceleration of environmental quality accompanied by an increase in people's welfare. Implementation of LONGGAR has been carried out since 2015. The Office of Maritime Affairs, Fisheries, Agriculture and Animal Husbandry (DKP3) of Makassar City, as a technical agency, is planning to develop a productive green alley garden, known as the garden alley (LONGGAR), with a budget of IDR. 123 million. The LONGGAR planning budget is IDR. 2.9 million per alley. This allocation comes from the 2015 Regional Budget (APBD) of Makassar. LONGGAR development was carried out in 42 aisles spread across 14 sub-districts in Makassar. Each district has three corridors as a pilot. To loosen this pilot, the sub-district determines which aisles will be developed. Getar 1000 Lorong Garden has met the achievement of the target in 2017 by fixing $90 \%$ of the total number of corridors in Makassar City. This makes LONGGAR innovation to receive international attention as a pilot program in revamping densely populated residential areas with a total of 506,000 reports in Google. Thus, LONGGAR is still feasible and has promising expectations.

\subsection{Over-reliance on high performers as source of innovation,}


Dependence on certain figures who have high performance causes most employees in the public sector to only become followers. When the figure disappears, the work experiences stagnation. The implementation of the LONGGAR program helps the Food Security Agency reach the village level. Where the Food Security Agency became the leading sector in the innovation of this program. One of the incentives provided by the agency is the assistance of seedlings and extension workers. Seedling assistance has spread to 14 sub-districts, and there are 49 extension agents[5]. However, there are still many people who do not understand the purpose of this program and where their crops will be sold. Makassar mayor's policy on Lorong Garden is less socialized so that some people do not understand and do not act as initiators of LONGGAR before there are officers who check the condition of the hallway and its worthiness. Similar barriers to implementation of LONGGAR were found in Rappocini District, which became a pilot hall in the implementation of the LONGGAR innovation program. After the mayor's visit to ASEN, the program was not taken care of because the people are busy workers and district officials and related agencies no longer routinely monitor the condition of the program.

Whereas one indicator of the success of government programs is that the government always socializes policies to the public so that they can know and understand the direction, goals and objectives of the policy and more importantly so that they can accept, support and even oversee the implementation of government policies[9]. In addition, the Allies Business Entity (BuLo) whose work is to marketing the yields from the LONGGAR and ambitions of community leaders who initiated LONGGAR have not been running optimally. This phenomenon shows that officers and market availability can be obstacles.

\subsection{Technologies available but constraining cultural or organizational arrangement,}

Innovation fails not because of the lack of technological support, but rather because of traditions or organizational policies that are not pro innovation. The level of education affects the understanding of the community to be involved in the Lorong Garden (LONGGAR) program. The community has not received counselling due to the limited extension workers and it is difficult to understand the program's action plan independently. As a result, people are not unwilling to participate, but there are limited information and resources. The government and related agencies as the implementor of the LONGGAR program did not work optimally because the implementing apparatus only installs the plants directly without the empowerment of basic education in urban hall-based agriculture for the community. They only directly install plants such as chillies, eggplants etc. and then left it. In addition, technical factors such as the lack of water supply from the Regional Water Company (PDAM) hamper plant maintenance. As with human resource management theory, program success is determined by competent human resources and the availability of supporting resources[10].

Another factor causing the improvement of the aisles has not been evenly distributed because the Allies Business Entity (BULo) program does not have a clear policy basis and has not been regulated in Regional Regulations (Perda) or mayor regulations (Perwali). From this, it can be questioned the readiness of the government apparatus for its readiness in carrying out the BULo program. It is feared that the existence of the BULo program which does not have a policy basis will not be realized to the maximum due to an unsustainable process in the formulation of the program. This is because it directly or indirectly has an impact on the implementation of the program because these process chains will bring vision to real activities and field operational guidelines for government officials[11]. 


\subsection{No rewards or incentives to innovate or adopt innovations,}

The ability to innovate cannot be regarded as an ordinary thing, but must be seen as something special so that it deserves to be rewarded. LONGGAR is different from other cleaning programs. For instance, sustainable agricultural assistance and extension is carried out by mentors, stakeholders and agricultural instructors from the Food Security Agency to ensure the program runs smoothly and successfully. Besides that, the community itself provides a pot for plants, soil and some fruit and vegetable seeds so that the community feels they have and can look after and care for their plants. This indicates LONGGAR has incentives for the community and government, so that it does not become an obstacle in its application. It shows that the success of a government program especially Lorong Garden can be seen from the public support for a policy. Generally, policies that provide incentives are usually easy to get public support. It is better if policies that are dis-incentive, such as having to strike a public pocket through self-help in purchasing materials and so on, will lack support, depending on people's awareness itself.

\subsection{Poor skills in active risk or change management,}

However, aspects of skills play an important role for the success of innovation. No matter how great the motivation of employees and the environment is conducive but not supported by adequate skills, innovation will stop as a discourse. The Lorong Garden (LONGGAR) becomes a solution to improve the aisles which so far seem dirty and arid. This program makes the hallways to be clean, green, and neatly arranged. Assistance on how to grow crops in a narrow yard, as well as continuous socialization by regional officials can ensure this program runs successfully. But, assistance in each region must be gradual due to the lack of existing staff, who must accompany 2 to 3 villages. This illustrates that the limited number of officers can be a limiting factor. In an effort to minimize these barriers, the Department of Food Security assigned 49 people with agricultural extension status with agricultural undergraduate background to assist Farmers Women's Groups (KWT) in the hallway in developing vegetable and fruit crops using the yard and the hallway.

\subsection{Short-term budget and planning horizons,}

The development of innovation both on an organizational and national scale must be planned well, in terms of annual, medium- and long-term perspectives. LONGGR budgeting is still unclear. There are those who say that this program is not budgeted, but there are also those who say that this program has a budget that has been allocated. Clarification from the Food Security Agency stated that the budget could only be allocated to some seeds and extension workers and the rest must have initiation and awareness from the community who voluntarily reformed the aisles and set aside income for the supply of seedlings and plant pot. So, the government still has not provided a collective budget for all LONGGAR needs, but the government is trying to involve the community to cover the budget shortfall through socialization and budget transparency to the public.

\subsection{Delivery pressures and administrative burdens,}


Relations between the government and the community are often based on a basis of mistrust. As a result, for a simple matter must include many requirements, lengthy procedures, and involving multiple actors. Things like this create pressure for anyone who is in a trance and removes the desire to innovate. The bureaucratic structure in the application of innovation has a significant influence, but so far, the bureaucratic procedures are complicated and complex. The context of the application of LONGGAR must be delivered by the urban village but the understanding obtained is still lacking, as is the understanding of the public agencies (SKPD), namely the Agriculture Agency and the Makassar City Food Security Agency who were present only important for LONGGAR, but the procedure was not so clear and uneven in the community. This gives an overview for the procedure for LONGGAR management to reach the most urban village levels, but the procedure is unclear and uneven.

Commitment, consistency and focus on a government policy or program in the implementation of the Lorong Garden (LONGGAR) program is something important, especially for government officials. For example, a policy proposed by Edi Suharto is a provision that contains principles to direct ways of acting that are planned and consistent in achieving certain goals[12]. In this case, consistent planned action and not mixing up each program is necessary, so that the LONGGAR program can run well because the success indicator of this program is that the Makassar City Community is satisfied with the improvement of the hallway at the district and sub-district level. This can then explain how the SKPD responsible for this program can be measured for its success in the welfare of the community.

\subsection{Culture of risk aversion,}

The success of a government program depends on community satisfaction and participation in the program. The character of the people in Makassar who seem apathetic and are busy with work routines and other things make this program implementation not optimal. The government has difficulty in accommodating community involvement that is difficult to regulate and can only be mobilized when there is assistance from the government. Existing aid, however, did not last long for the community, for example the assistance of perishable plastic pots and seeds which were difficult to maintain. In addition, the community depends on the government who wants repeated coaching. Another obstacle encountered in terms of coaching this program is changing the mindset of urban communities to become people who understand about urban farm. In addition, the weather is a factor hampering the cultivation of chili and makes the LONGGAR program not optimal because the community is not committed to conducting maintenance and improvement. This illustrates that the obstacles to achieving innovation goals, namely the mindset of the community oriented to individual needs and assistance from the government, do not apply long term.

\section{Conclusion}

The Lorong Garden or LONGGAR Program is a form of public sector innovation in urban spatial planning and densely populated settlements. The obstacles encountered in applying the LOOSE innovation are the limited number of extension workers, lack of understanding, level of public education, availability of facilities and infrastructure, such as PDAM water supply and community culture. Based on this, the government must create budget transparency, Standard Operating Procedures (SOP) for LONGGAR, and optimizing the involvement of youth and 
community leaders. The identification of these obstacles can be used by the government to improve the success of Lorong Garden's innovation in Makassar.

Acknowledgements. This research was supported by Hasanuddin University. We would like to thank the Government of Makassar city for providing the data required in this research. All errors and omissions are our own.

\section{References}

[1] Widodo, T. U.: Inovasi Sebagai Keniscayaan Baru Dalam Ilmu dan Praktek Administrasi Publik di Indonesia (2016)

[2] Rogers, E. M.: Diffusion of innovations-Third Edition (1983)

[3] Mulgan, D. and Albury, G.: İnnovation in Tha Public Sector (2003)

[4] Central Bureau of Statistic Makassar: Makassar Municipality in Figures 2018, Makassar (2019)

[5] Badan Ketahanan Pangan Kota Makassar: Profil Inovasi Getar 1000 Longgar, Makassar (2017)

[6] Moleong, L. J.: Metodologi Penelitian Kualitatif (Edisi Revisi), in PT. Remaja Rosda Karya, (2017)

[7] Miles, M. B. Huberman, A. M and Saldana, J.: Cross-case data analysis, in Qualitative data analysis: An expanded sourcebook (2014)

[8] Suwarno, Y and Lan S.:Inovasi Di Sektor Publik, J. Adm. Publik, Vol. 5, no. 2 (2008)

[9] Gafur, A.: Memanfaatkan Pekarangan Mendukung Program Lorong Garden (Longgar), Dalam Materi Pelatihan, Makassar, (2015)

[10] Perry J. L and Hondeghem, A.: "Building theory and empirical evidence about public service motivation, Int. Public Manag. J (2008)

[11] Nurfahmiati, H.: Pemberdayaan Masyarakat Melalui Program Badan Usaha Lorong (Studi Kasus di Kecamatan Rappocini Kota Makassar), J. Eprints Univ. Negeri Makassar (2018)

[12] Jannah, M. "Implementasi Kebijakan Larangan Parkir di Bahu Jalan dalam Mengatasi Kemacetan di Kota Makassar," J. Kolaborasi, vol. Volume 1 N, pp. 238-250 (2015) 